INTERACTION: Jurnal Pendidikan Bahasa; Vol. 7, No. 1; Mei 2020

ISSN: 2406-9558; E-ISSN: 2406-9566

\title{
An Analyzing on the Students Error in Using Conditional Sentence
}

\author{
Kustianah \\ kustianah@gmail.com \\ MTs Muhammadiyah 04 Klamalu
}

\author{
Ari Wibowo \\ ariwibowo@gmail.com \\ Universitas Pendidikan Muhammadiyah Sorong
}

\begin{abstract}
In this study, the writer want to analyze the student error in using conditional sentence and involve all case in conditional sentence. The method of this research is error analysis. In this research, the researcher wishes to know how is the students of the second grade at Madrasah Tsanawiyah Muhammadiyah 04 Klamalu competence in using conditional sentence type III especially in tenses "simple past perfect tense and simple future perfect tense." The researcher gave the test to the students without the treatment the researcher want to know just one the cause of errors about the use of conditional sentence type III "simple past perfect tense and simple future perfect tense." The result showed that the causing error of the students in using conditional sentence are carelessness, first language using, translation, the facility of students learning like English book, the method of teaching and the students themselves. After the analysis kind of conditional sentence the writer to identification the kinds of error and persentage of students error, result of reserch are: omission the total error are 10 error, the persentage is 7, $04 \%$. Addition the total of error 14 error, the persentage is $9,86 \%$. Miss- ordering error is 80 error, the persentage is $56,34 \%$ and subtitution error is 38 error, the persentage is $26,76 \%$. So the total of students error are 142 error and the persentage is $100 \%$.
\end{abstract}

Keywords: Students Error; Conditional Sentence

\section{INTRODUCTION}

Conditional Sentence is a hypothetical situation of past time, one which did not occur. Conditional sentence consist of two clause, they are a dependent clause beginning with if (or another conjunction performing the same general function) and main clause. The main clause give the result of if clause (George E Wishon \& Julia M Burks 2006: 249).

According to Betty SchramperAzzar (2003) conditional sentence is consist of if clause (which present condition) in conditional sentences as a question's sentences. There are three types of conditional sentences, they are: conditional sentence explain about an 
activity that contrary the other activities. The most general of conditional is real conditional an unreal conditional. Sometimes it calls if - clause. It describes about imagination according to the fact. Conditional sentence describes regret that happened in the past time and the last one is zero conditional, it means general truth.

Thomson and Martinet (2003:197) say that conditional sentence has two parts are: if clause and main clause. They also state that conditional sentence has three kinds of type; in which each kind contains a different pair of tenses in some variations. Those three types of conditional sentence named by Thomson and Martinet (197-200) as type I is probable or real conditional, type II and type III are improbable or unreal conditional sentence categorized into a conditional sentence using if.

Conditional sentence is the item in English which usually using in the activities. It's too important for our students in increasing language skill and developing their grammar. Many advantages will get an English students if they understand grammar as well therefore, the writer chooses conditional sentence as the subject research.The present study tried to analyze the errors students in using conditional sentence, right in writing report or speaking report. The purpose of study were present causes the errors students' in conditional sentence while their writing or speaking English.

The writer choose conditional sentence, because the students has was familiar with the material. But sometimes they still confuse to use sentence and the writer makes use the test to find the students conditional sentence error, because the test can demonstrate. How well students master the material, the teacher can get the feedback and also know where we are in order to know. That is reason the writer want to analyzing the student error in using conditional sentence and the writer involve all case in conditional sentence.

\section{LITERATURE REVIEW}

\section{Previous Study}

In the previous research writer took on thesis writer by Fani Saftiani Lindar (2009) in faculty in Gendarme university.Her thesis "the mastery of conditional: a case study of students of faculty of letters at second grade in Gendarme university. She says that this analysis, the students ability in mastering conditional sentences. The population of this research is the students of faculty of letter in Gendarme university in the academic year of 2007-2008. Where as 40 of them are taken as sample, to be taken randomly. To conduct this research the writer used descriptive Quantitative, research to analysis the ability of the students of faculty of letter in mastering conditional sentences. based on the analysis , the percentage of error in understanding conditional sentences are 30 , $42 \%$ I type I , 68, 57\% in type II, and $67,85 \%$ type III. The result of this research 
showed that most of the students performed unsafe factory, most of them got less them $60 \%$ of correct 1 hems. It means that their English are still poor and they have difficulties to master conditional sentences.

Pratama (2012) researched about analyze on using conditional sentence at the second grade students at SMA MEI Ciputat. The population are 30 students, the result research are: have many errors to be make of students there are; word choice with presentation $55,8 \%$, verb tense $39,8 \%$, omit a word $1,94 \%$, add a word $0,97 \%$, meaningnot clear $0,97 \%$ and word form $0,48 \%$. The students to do make error by using conditional sentence, because transfer interlingua which system, arrange, and pattern of students tongue language with presentation $46,61 \%$, context or not contextual of pattern $38,83 \%, 14,07 \%$, first language and the language learning, ending $0,49 \%$ of error students because strategies communication which student have manner they self by tongue language and the error of learning language.

\section{Error}

Many linguists have defined differently what and error is based on their own concept Vicki Fromkin and Robert Rodman (1978:361). States that the human brain is able not only to acquired store the mental grammar.But also access that linguistic store house to speak and understand what is spoken, meaning they are against the grammatical rule of the language and result in uncap table utterances.In second language learning they occur because the learner has not internalized the grammar of the second language. In order words, the students arise out of lack of competence, therefore errors are systematical. Furthermore, they make a distinctions between errors, mistakes, and lapses. Mistakes arise when the speaker fails to match the language to the situations and result in appropriate utterances. Lapses, in the other hand, arises out tiredness, nervousness; or stain which result in slip of tongue, false starts confusion of structure, etc. Both mistake and lapses are not systematical and belong to phenomena of performance.

Dullay in Brown (2004:170) uses the term "errors " to refer to any deviations from a selected norm of language performance, and matter what the characteristics or causes of the definition might be. They also explain that the norm used to identify the errors may be anyone of the dialect of other varieties of language the native speakers uses. The terms errors, as noted by Dullay above is used for the systematic deviations due to the learners still developing knowledge of the target language rule. System or for idiosyncrasies in the inter language of the learner which are direct manifestations of system with which leaner is operating at the time. In this present study the researcher prefer to use the definition of errors given by him on the consideration that this study is not intended to differentiated between errors and mistakes. 
INTERACTION: Jurnal Pendidikan Bahasa; Vol. 7, No. 1; Mei 2020

ISSN: 2406-9558; E-ISSN: 2406-9566

\section{Category of Errors in Errors Analysis}

Developmental, inter - lingual, ambiguous and other errors Further more, based on surface strategy taxonomy. Soetikno ( 1996 : 181) give emphasis on the ways surface structure is altered. Learner may omit necessary items of add unnecessary ones, they may misfire item or miss order them. Thus, the errors may be in the from of omission, additions, miss formation, and miss ordering errors types.

Omissions error are characterized by the absence of an item that most appear in a well - formed utterance. Although any morpheme or word in a sentence is a potential candidate for omission, some types for most home are omitted than others. Additional errors are the opposite of omission. They are characterized by the presence of an item, which must not appear in a well - formed utterance. Additional errors include double marking, regularization and sample addition that is an addition that is not double marking or regularization.

Miss formation errors are characterized by the use of the wrong from of morpheme or structure, while in omission errors the items is not supplied at all, in miss - formations error the learners. Supplies something although it is in correct miss ordering errors are characterized by the incorrect placement of a morpheme or group morphemes in a utterance. This study has the some purpose as Dullay's statement in the classification of error types. The error classifications is intended as an aid to present data rather than to create a basic for extensive speculating concerning the source of errors.

Based on the statement above the writer take a conclusion that error is the human brain is not able to access information, Because, they to do : carelessness, first language, limited translation, structure, arise out tiredness and nervousness.

\section{Conditional Sentence}

Conditional sentence consist of two clause, they are a dependent clause beginning with if (or another conjunction performing the same general function) and main clause. The main clause give the result of if clause (George E wishon \& julia M Burk 2006: 257 ). According to Betty Schramperm Azzar (2003) a conditional sentence is consist of if clause (which present condition) in conditional sentences as a question's sentences. There are three types of conditional sentences, they are: conditional sentence explain about an activity that contrary the other activities. The most general of conditional is real conditional an unreal conditional. Sometimes it calls if - clause. It describes about imagination according to the fact. Conditional sentence describes regret that happened in the past time and the last one is zero conditional, it means general trunt.Simple past perfect tense is form of time that used to asked a happened / accident the last time that perfect finish before to do.

Example : 1). She had been at school. 2). you had been there a long time. 
INTERACTION: Jurnal Pendidikan Bahasa; Vol. 7, No. 1; Mei 2020

ISSN: 2406-9558; E-ISSN: 2406-9566

\section{METHOD}

\section{Design and Sample}

The method of this research is error analysis. It belong to the descriptive research, because this research tells and interpret data by the facts, situation, variable and phenomenon when this research goes on and it presented whatever there is (Drs. Subana 2004:26), in this research the researcher wishes to know how is the students of the second grade at Madrasah Tsanawiyah Muhammadiyah 04 Klamalu competence in using conditional sentence type III especially in tenses "simple past perfect tense and simple future perfect tense." In this research the researcher gave the test to the students without the treatment the researcher want to know just one the cause of errors about the use of conditional sentence type III "simple past perfect tense and simple future perfect tense." And to find out the kinds of most dominant the error students make. The data can be gotten from part of representative of population by using technique. It is technique of taking part of representative of population of sample at random. It means that all individuals in the population get the some chance to be selected to become the member of sample. Mean while the sample of this research is 20 students.

\section{Instrument and Procedure}

Iqbal hasan (2004:16) says test is an instrument that used to measure capability, knowledge, intelligence, and talent of individual of group. Instrument used to get data in this research was in the form of topics list used in the conditional sentence. The instrumentused in the research should be appropriate with the variable of research. So in order to get data relating to each variable, the research used the form of written test as instrument for asking the students to produce their language in the form of written conditional sentence in the class.

Collecting the data is a way to get some data used to a research. With the aim, that in order the study could be done well and the result becomes accurate and scientific research. The data is very needed in a research to make a report accurately. The writer gave the students explain about the materials of test, and than distributesthe test sheet to the students. After that, the writer asks to the students to do the test about conditional sentence " simple past perfect tense and simple future perfect tense". Finally, the writer collects the students sheet test.

\section{Data Analysis}

After the writer got all of the kinds and factor causes of error, the last step is making tabulation of error with counting to get the data. With making tabulation of error, the writer and the reader could know how the result of the research is. To count the student error will be showed in percentage form, as follow: 
INTERACTION: Jurnal Pendidikan Bahasa; Vol. 7, No. 1; Mei 2020

ISSN: 2406-9558; E-ISSN: 2406-9566

$\mathrm{P}=\mathrm{F} / \mathrm{N} \times 100 \%$

Note:

P: Percentage of student error

F: Frequency of student error

$\mathrm{N}$ : Total error

\section{RESULT AND DISCUSSION}

Based on the data analysis kinds of error, the writer found on students do made error in using conditional sentence, the writer found the caused of error there are: carelessness, first language, tranlation and the other caused are: the first facility of students learning, like english book. The second the method of teaching and the third factor is the students themselves and the last factor caused over or are inter lingual tranfer and intra lingual transfer.

The writer do made research at second grade Madrasah Tsanawiyah Muhammadiyah 04 Klamalu. The population that consist of 20 students, with collecting data by writen test and the analysis data using descriptive quantitative.

Based on the analysis the data that the writer found kinds of conditional sentence, the persentage simple past perfect tense is (47 error or $42,73 \%$ ) and simple future perfect tense (63 error or $57,27 \%$ ) total errors (110 error or $100 \%)$.

After the analysis kind of conditional sentence the writer to identification the kinds of error and persentage of students error, result of reserch are: omission the total error 10 error, the persentage is $7,04 \%$. Addition the total of error 14 error, the persentage is 9 , $86 \%$. Miss- ordering the total error 80 error, the persentage is $56,34 \%$. and Subtitution the total error 38 error, the persentage is $26,76 \%$. So total all of students error 142 error and the persentage is $100 \%$.

\section{CONCLUSION}

In this thesis, the writer can take that the language program of second year's student of Madrasah Tsanawiyah Muhammadiyah 04 Klamalu do not know yet how to use conditional sentence.

After analyzing the data, the researcher found four kind of error, simple past perfect tense (47 error or $42,73 \%$ ) and simple future perfect tense (63 error or 57,27\%). And then the total kinds of error are :142 error conditional sentences. Those errors fulfill four categories of surface strategy taxonomy. There are omissions (10 errors or 7,04 $\%$ ), addition ( 14 errors or 9,86\%), subtitution (38 errors or $26.76 \%$ ) and Miss-ordering ( 80 errors or $56,34 \%$ ). Therefore, the Miss-ordering error has the highest frequency 
INTERACTION: Jurnal Pendidikan Bahasa; Vol. 7, No. 1; Mei 2020

ISSN: 2406-9558; E-ISSN: 2406-9566

(142 errors or $100 \%)$. And beside of any error that was explained above, the writer also found very much mistake that student made.

In the analyzing data the research found the students extent in comprehending conditional sentence, those are the students still limited in understanding pattern conditional sentence, so the students do made error carelessness, first language and translation.

Based on the analyzing the data that writer found on student made error in using conditional sentense, the writer found the cause of error into three types, those are facility of students learning, method of teaching and the students themselves. And factors cause over or are Interlingua transfer and intralingua transfer. Interlingua transfer is the errors caused by the mother tongue influence. While, intralingua transfer is the error caused by the target language influence.

After analyzing and describing error analysis in language learning, the writer then concludes that error analysis is required in developing or increasing the techniques in teaching English. By doing the error analysis, a teacher can concentrate on the materials in which most learners made error; a teacher can also evaluate himself whether he succeeds in teaching or not; and finally he can improve his techniques in teaching by preparing systematic materials.

\section{REFERENCE}

Arikunto, S. (2006). Procedure Penelitian Suatu Pendekatan Praktek. Jakarta: PT. Bina aksara.

Betty, S. A. (2003). Fundamental of English Grammar, third Edition With Answer Key: Longman Group.

Bambang, M ., \& Syamsul, A. (2007). Tenses CV. Buana Raya Solo.

Brown. H. C. And Burty M. (2004).Principle of Language Learning and Teaching Regnes Engle Wood Cliffs: Prentience Idall.

Brown. (2004). You Can Learn Without Goofing and Analysis of Children Second Language Errors. In . J . C.

Fani, S. L. (2009). The Mastery of Conditional Sentence in Gunadarma University. Published Thesis. Universitas Sanata Darma.

George, E. W., \& Julia M. B. (2006: 257). English Sentence Structure. Longman Group. 
INTERACTION: Jurnal Pendidikan Bahasa; Vol. 7, No. 1; Mei 2020 ISSN: 2406-9558; E-ISSN: 2406-9566

Hasan, I. (2004). Analysis Data Penelitian. Jakarta: Bumi Aksara.

Horn. (2003). Error Analysis Perspective on Second Language Acquisition London: Longman Group.

Oxford. Learners Pocket Dictionary. New Addition university press.

Partino, H. R.(2006). Methodology Penelitian Kuantitatif. Yogyakarta Pustaka. Mahasiswa.

Pratama, M. R. (2012). Analyze on Using Conditional Sentence At SMA Mei Ciputat. Published Thesis.

Schumman., \& Stenson. (2003). Error Analysis and Second language Strategies. Guest Article Archive.

Subana. (2004). Research methodology. Jakarta : PT Raja Grafindo Persada.

Vicki, F. R. R. (2008). Introduction to Language. Univercity Calivornia.

Sunardi, H. (2002). Error Analysis in the Teaching of English. Petra Journal.

Thomson., \& Martinet. (2003). What is part of conditional sentence?.http: // www.getsmartseries.com/. 